\title{
Tukey HSD Post Hoc Test untuk Perbandingan Karakteristik Lingkungan dan Sumber Daya Provinsi-Provinsi di Indonesia
}

Bunga Mardhotillah, Syamsyida Rozi, dan Zuli Rodhiyah

Fakultas Sains dan Teknologi, Universitas Jambi, Jambi, Indonesia

Email: bunga.mstat08@unja.ac.id, syamsyida.rozi@gmail.com, zuli.rodhiyah@unja.ac.id

\section{Info Artikel}

Diterima: 20 Agustus 2021

Disetujui: 27 Agustus 2021

Dipublikasikan: 31 Agustus 2021

Alamat Korespondensi:

bunga.mardhotillah@gmail.com

Copyright @ 2021 Jurnal

Engineering

This work is licensed under the Creative Commons Attribution International License (CC BY $4.0)$.

\begin{abstract}
Abstrak
Karakteristik Lingkungan memiliki beberapa komponen, di antaranya sumber daya lingkungan dan kualitas lingkungan. Kualitas Lingkungan dapat diukur dengan berbagai indeks, beberapa di antaranya adalah Indeks Kualitas Udara dan Indeks Kualitas Air. Penelitian ini dimaksudkan untuk mengetahui persamaan dan perbedaan Karakteristik sumber daya dan kualitas lingkungan yang diperlukan dalam penentuan daerah tujuan studi komparasi/studi tiru dari satu provinsi ke provinsi lainnya dan rekomendasi kebijakan sektor lingkungan hidup sebagai bahan penyusunan regulasi dan penggunaan teknologi yang tepat dalam mengatasi permasalahan lingkungan. Penelitian ini menggunakan analisis variansi dan uji lanjut Tukey HSD. Analisis Variansi Perbandingan Karakteristik Lingkungan serta sumber daya provinsi provinsi pada empat pulau besar di Indonesia menunjukkan Nilai $F$ Statistics yang signifikan. Hasil Uji Lanjut Tukey HSD ditemukan bahwa perbedaan Luas Hutan Konservasi yang signifikan ditemukan pada Pulau Jawa dan Kalimantan. Luas Hutan Produksi Tetap Pulau Kalimantan berbeda dengan tiga pulau lainnya. Indeks Kualitas Udara dan IKLH Pulau Jawa berbeda dengan 3 pulau yang lainnya. Indeks Kualitas Air dan Indeks Kualitas Air Pulau Jawa berbeda secara nyata dengan ketiga Pulau lainnya. Indeks Kualitas Tutupan Lahan, Indeks Kualitas Tutupan Lahan pada Pulau Jawa berbeda secara nyata dengan Pulau Kalimantan dan Pulau Sulawesi. Luas Ekosistem Terumbu Karang pada Pulau Jawa dan Pulau Sulawesi juga berbeda secara nyata. Luas Hutan Produksi Terbatas, tidak terdapat perbedaan yang signifikan untuk Pulau Jawa dan Pulau Kalimantan.
\end{abstract}

Kata kunci: Uji Lanjut Tukey HSD, Analisis Variansi, Sumber Daya Lingkungan, Rekomendasi Kebijakan Sektor Lingkungan 


\section{Pendahuluan}

Ketersediaan sumber daya dan energy mempengaruhi berbagai macam kegiatan industry dalam rangka pemenuhan kebutuhan manusia. Perkembangan proses produksi memerlukan sumber bahan baku yang besar, alat serta mungkin akan menimbulkan limbah bagi lingkungan. Adanya emisi limbah dari berbagai macam sektor ke lingkungan merupakan suatu permasalahan yang penting untuk di soroti. Berbagai upaya pengendalian dan pemantauan pencemaran juga harus di lakukan. Sebagai salah satu upaya pemantauan di berbagai sektor lingkungan hidup, indeksasi menjadi salah satu tolok ukur penilaian kualitas lingkungan yang banyak dan umum di lakukan. Namun dikarenakan adanya berbagai macam perbedaan permasalahan lingkungan serta faktor-faktor lingkungan yang ada pada setiap daerah, menyebabkan perlunya berbagai macam instansi pemerintahan untuk melakukan suatu studi banding dari satu daerah ke daerah lain dalam upaya untuk mempelajari. Oleh karena itu, studi ini bermaksud untuk membandingkan dan memetakan secara statistik berbagai macam indeksasi kualitas lingkungan antara satu daerah dengan daerah lain pada empat pulau di Indonesia. Dengan adanya studi ini, diharapkan bisa menjadi acuan pengambilan kebijakan tentang studi banding pengelolaan lingkungan antara satu daerah dengan daerah lainnya.

Menurut data publikasi BPS pada Statistik Lingkungan Hidup Indonesia (SLHI) 2020 dan data Indeks Kualitas Lingkungan Hidup atau yang disingkat dengan IKLH (2020) tutupan lahan di Indonesia berupa hutan adalah seluas 93.526.200 Ha, dan luas tutupan lahan non-hutan adalah 94.225.700 Ha. Kondisi ini cukup memprihatinkan, karena dari tahun ke tahun, luas hutan di Indonesia semakin berkurang. Rata - rata produksi kayu hutan dalam beberapa tahun terakhir untuk kayu bulat adalah $42.883 .712 \mathrm{~m}^{3}$, kayu gergajian $2.034 .600,4 \mathrm{~m}^{3}$, plywood dan LVL $3.898 .153,8 \mathrm{~m}^{3}$, papan tipis $1.042 .348,2 \mathrm{~m}^{3}$, serpih kayu 29.138.299,2 $\mathrm{m}^{3}$, dan bubur kertas (Pulp) 6.857.693,4 $\mathrm{m}^{3}$.

Penelitian dan kajian terkait statistik lingkungan hidup tidak lepas dari berbagai komponen dan subkomponen, dikarenakan ruang lingkup sektor lingkungan hidup sangat luas. Setidaknya terdapat 21 subkomponen penyusun Statistik Lingkungan Hidup Indonesia (SLHI) yang disajikan dalam puluhan tabulasi. Subkomponen tersebut di antaranya adalah kondisi fisik dan kualitas lingkungan hidup, tutupan lahan, ekosistem dan keanekaragaman hayati, lahan, sumber daya mineral, energi, tanah, hutan, dan air. Subkomponen lainnya merupakan penyusun komponen lingkungan hidup berupa peristiwa ekstrim dan bencana, pemukiman dan kesehatan lingkungan, partisipasi, pengelolaan, dan perlindungan lingkungan. Tulisan ini menyoroti/menitik beratkan pada kondisi dan kualitas lingkungan, serta sumber daya lingkungan.

Karakteristik kondisi fisik, kualitas, dan sumber daya lingkungan pada tiap provinsi umumnya berbeda - beda dan hanya terdapat beberapa variable lingkungan hidup yang mengindikasikan kesamaan pada beberapa daerah. Belum adanya kajian mendalam terkait persamaan/perbedaan karakteristik lingkungan dan sumber daya tingkat provinsi dengan pulau sebagai blok masih sangat jarang ditemukan dalam berbagai referensi, karena itu penulis tertarik untuk menganalisis secara keilmuan statistika, mengacu pada metode statistika ekologi terkait persamaan dan perbedaan karakteristik kondisi, kualitas dan sumber daya lingkungan pada provinsi - provinsi di Pulau Jawa, Pulau Sumatera, Pulau Kalimantan, dan Pulau Sulawesi melalui analisis variansi dan uji lanjut (Post Hoc Test) menggunakan uji tukey HSD.

Secara matematis tukey HSD post hoc test dirumuskan sebagai berikut:

$$
H S D=\text { Tukey }_{\alpha ; p ; d b=d b E r r o r} \frac{1}{\sqrt{2}} \sqrt{M S(W)\left(\frac{1}{n_{i}}+\frac{1}{n_{j}}\right)}
$$




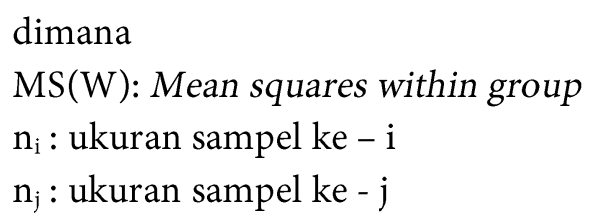

Uji tukey yang dikenal dengan uji beda nyata jujur atau tukey's HSD (honest significant difference) test, menguji ada tidaknya ketidaksamaan antara rata - rata kelompok perbandingan, tetapi tidak menampilkan hasil uji hipotesis perbedaan antar pasangan rata - rata kelompok (Harlan, 2018).

Sumber daya energi dan beberapa sumber daya lainnya pada SLHI hanya menyajikan data tingkat nasional (tidak menyajikan data tingkat provinsi) sebagaimana uraian dalam beberapa paragraf di atas, sehingga analisis variansi dan post hoc test dibatasi hanya pada beberapa sumber daya lingkungan yang datanya tersedia hingga tingkat provinsi. Sumber daya lingkungan yang tidak tersedia data tingkat provinsi pada SLHI, hanya dideskripsikan sebagai pengayaan wawasan pada tulisan ini. Hasil analisis variansi serta post hoc test untuk data SLHI ini diharapkan menjadi salah satu pertimbangan pemerintah pusat dalam perumusan kebijakan sektor lingkungan hidup, serta menjadi referensi bagi pemerintah daerah/provinsi yang bermaksud melaksanakan studi komparasi maupun studi tiru/adaptasi ke daerah/provinsi lainnya berdasarkan persamaan/ketidaksamaan karakteristik lingkungannya, khususnya bagi pemerintah provinsi di Pulau Jawa, Pulau Sumatera, Pulau Kalimantan, dan Pulau Sulawesi.

\section{Metode Penelitian}

Penelitian ini merupakan penelitian kuantitatif menggunakan statistika inferensif, waktu penelitian pada Bulan Juli 2021 dan penelitian dilaksanakan di FST Universitas Jambi dengan sampel penelitian provinsi - provinsi pada Pulau Jawa, Pulau Sumatera, Pulau Kalimantan, dan Pulau Sulawesi. Target/sasaran penelitian ini adalah menyajikan hasil post hoc test ANOVA berupa kesamaan/ketidaksamaan karakteristik lingkungan provinsi di Pulau Jawa, Sumatera, Kalimantan, dan Sulawesi. Prosedur penelitian adalah menganalisis data sekunder yang bersumber dari ILHK 2019 dan SLHI 2020.

Teknik analisis data menggunakan Tukey HSD Test sebagai salah satu metode Post Hoc Test ANOVA menggunakan software SPSS. Adapun subkomponen sektor lingkungan hidup yang diteliti dibatasi hanya beberapa subkomponen saja, antara lain: ILHK Provinsi - Provinsi di Indonesia tahun 2019, Indeks Kualitas Udara(IKU) tingkat provinsi, Indeks Kualitas Air(IKA) tingkat provinsi, luas penutupan lahan indonesia di dalam dan di luar kawasan hutan menurut provinsi, luas mangrove Indonesia menurut provinsi, serta luas ekosistem terumbu karang menurut provinsi. Data luas mangrove terlebih dahulu ditransformasi, data luas mangrove yang tersedia adalah dalam satuan Ha, kemudian ditransformasi menjadi dalam satuan ribu $\mathrm{Ha}$, hasil analisis variansi variable - variable disajikan dalam ANOVA. Perbandingan angka indeks terkait lingkungan hidup dianalisis terpisah dengan karakteristik berupa luas tutupan lahan, Luas mangrove, dan Luas terumbu karang. Kemudian ANOVA dengan statistik F yang signifikan, dianalisis lebih lanjut dengan Tukey HSD Post Hoc Test. 


\section{Hasil Penelitian dan Pembahasan}

Karakteristik awal sumber daya di setiap provinsi akan dikarakterisasi menggunakan statistika deskriptif. Menurut Subagyo (2003) statistika deskriptif mengacu pada statistika yang berhubungan dengan pengumpulan data, penyajian, pendefinisian nilai statistik, pembuatan grafik atau penggambaran sesuatu data. Penggambaran melalui statistika deskriptif bertujuan untuk menyajikan data dalam bentuk yang lebih mudah dipahami atau dibaca. Deskripsi data penelitian ini dapat dilihat pada tabel 1.

Tabel 1. Summary Statistics Karakteristik dan Sumber Daya Lingkungan 27 Provinsi pada 4 Pulau

\begin{tabular}{|c|c|c|c|c|c|}
\hline \multicolumn{6}{|c|}{ Descriptive Statistics } \\
\hline & $\mathrm{N}$ & Minimum & Maximum & Mean & Std. Deviation \\
\hline Luas Hutan Konservasi (ribu Ha) & 27 & ,0000 & 844,3000 & 330,929630 & 271,3324966 \\
\hline Luas Hutan konservasi (ribu $\mathrm{Ha}$ ) & 27 &, 0000 & 2848,2000 & 676,559259 & 740,7860027 \\
\hline $\begin{array}{l}\text { Luas Hutan Produksi Terbatas (ribu } \\
\mathrm{Ha} \text { ) }\end{array}$ & 27 &, 0000 & 5045,2000 & 629,948148 & 1154,5859572 \\
\hline Luas Hutan Produksi Tetap (ribu Ha) & 27 &, 0000 & 4022,3000 & 767,488889 & 1111,1323425 \\
\hline Luas Mangrove (ribu Ha) & 27 &, 0000 & 183,3057 & 42,223980 & 51,4490052 \\
\hline $\begin{array}{l}\text { Luas Ekosistem Terumbu Karang (ribu } \\
\mathrm{Ha)}\end{array}$ & 27 &, 0000 & 328,7571 & 52,859902 & 89,8770316 \\
\hline Indeks Kualitas Udara & 27 & 67,97 & 93,79 & 87,3189 & 5,98098 \\
\hline Indeks Kualitas Air & 27 & 35,37 & 69,29 & 53,4507 & 7,42611 \\
\hline Indeks Kualitas Tutupan Lahan & 27 & 24,66 & 87,94 & 57,7185 & 17,59818 \\
\hline Indeks Kualitas Lingkungan Hidup & 27 & 42,84 & 80,87 & 65,3252 & 9,54598 \\
\hline Valid N (listwise) & 27 & & & & \\
\hline
\end{tabular}

Tabel 1 memuat statistik deskriptif karakteristik dan sumber daya lingkungan provinsi - provinsi pada 4 pulau besar di Indonesia tahun 2020, yakni pada Pulau Sumatera, Jawa, Kalimantan, dan Sulawesi sebanyak 27 Provinsi. Rata - rata luas hutan konservasi provinsi pada 4 pulau besar di Indonesia adalah $330.929,63 \mathrm{Ha}$, dengan simpangan baku 271.332,497 Ha, serta luas tertinggi hutan konservasi provinsi pada 4 pulau tersebut senilai $844.300 \mathrm{Ha}$ (Provinsi Aceh). Rata - rata luas hutan konservasi provinsi pada 4 pulau besar di Indonesia adalah 676.559,259 Ha, dengan simpangan baku 740.786,003 Ha, serta luas tertinggi hutan konservasi provinsi pada 4 Pulau tersebut senilai 2.848.200 Ha (Provinsi Kalimantan Timur). Rata rata luas hutan produksi terbatas provinsi pada 4 pulau besar di Indonesia adalah 629.948,148 Ha, dengan simpangan baku 1.154.585,9572 $\mathrm{Ha}$, serta luas tertinggi hutan produksi terbatas provinsi pada 4 pulau tersebut senilai 5.045.200 Ha (Provinsi Kalimantan Timur). Rata - rata luas hutan produksi tetap provinsi pada 4 pulau besar di Indonesia adalah 767.488,889 Ha, dengan simpangan baku 1.111.132,34 Ha, serta luas tertinggi hutan produksi tetap provinsi pada 4 pulau tersebut seluas $4.022 .300 \mathrm{Ha}$ (Provinsi Kalimantan Timur). Rata - rata luas mangrove pada 4 pulau besar di Indonesia adalah 42.223,98 Ha dengan simpangan baku 51.449,0052 Ha, serta luas maksimum mangrove adalah seluas 183.305,7 Ha (Provinsi Kalimantan Timur). Rata - rata luas ekosistem terumbu karang pada 4 pulau besar di Indonesia adalah 58.859,902 Ha dengan simpangan baku 89.877,0316 Ha, serta Luas maksimum ekosistem terumbu karang adalah seluas 328.757,1 Ha (Provinsi Sulawesi Selatan). Rata - rata Indeks Kualitas Udara (IKU) pada provinsi - provinsi di 4 pulau besar di Indonesia adalah 87,32 dengan simpangan baku 5,98, serta IKU tertinggi adalah senilai 93,79 (Provinsi Kalimantan Utara). Rata - rata Indeks Kualitas Air pada provinsi - provinsi di 4 pulau besar di Indonesia adalah 53,45 dengan simpangan baku 7,43 serta Indeks Kualitas Air tertinggi adalah senilai 69,29 (Provinsi Kepulauan Bangka Belitung). Rata - rata Indeks Kualitas Tutupan Lahan pada provinsi - 
provinsi di 4 pulau besar di Indonesia adalah 57,72 dengan simpangan baku 17,60 serta Indeks Kualitas Tutupan Lahan tertinggi adalah senilai 87,94 (Provinsi Kalimantan Timur dan Provinsi Kalimantan Utara). Rata - rata Indeks Kualitas Lingkungan Hidup pada provinsi - provinsi di 4 pulau besar di Indonesia adalah 65,33 dengan simpangan baku 9,55 serta Indeks Kualitas Lingkungan Hidup tertinggi adalah senilai 80,87 (Provinsi Kalimantan Timur).

Selanjutnya untuk melakukan analisis variansi beserta Post Hoc Test-nya, hanya dapat dilakukan jika data berdistribusi normal. Berikut ini uji normalitas data masing - masing variabel untuk tiap pulau menggunakan Uji Kolmogorov Smirnov disajikan pada Tabel 2. Jika data tidak berdistribusi normal, maka data tersebut tidak diikutsertakan dalam Analisis Variansi. Hasil Uji Normalitas data adalah sebagai berikut:

Tabel 2. Hasil Uji Kolmogorov Smirnov untuk Data Kondisi, Kualitas, dan Sumber Daya Lingkungan

\begin{tabular}{|c|c|c|c|c|}
\hline No & Variabel/Pulau-Group & $\begin{array}{c}\text { Statistik } \\
\text { Kolmogorov - } \\
\text { Smirnov Test }\end{array}$ & $\begin{array}{l}\text { Asymp. } \\
\text { Sig (2 - } \\
\text { tailed) }\end{array}$ & Keterangan \\
\hline 1 & Luas Hutan Konservasi/Sumatera & 0,167 & 0,200 & Normal \\
\hline 2 & Luas Hutan konservasi/Sumatera & 0,209 & 0,200 & Normal \\
\hline 3 & Luas Hutan Produksi Terbatas/Sumatera & 0,332 & 0,003 & Tidak Berdist. Normal \\
\hline 4 & Luas Hutan Produksi Tetap/Sumatera & 0,217 & 0,199 & Normal \\
\hline 5 & Luas Mangrove/Sumatera & 0,522 & 0,000 & Tidak Berdist. Normal \\
\hline 6 & Luas Ekosistem Terumbu Karang/Sumatera & 0,299 & 0,011 & Tidak Berdist. Normal \\
\hline 7 & Indeks Kualitas Udara/Sumatera & 0,219 & 0,192 & Normal \\
\hline 8 & Indeks Kualitas Air/Sumatera & 0,167 & 0,200 & Normal \\
\hline 9 & Indeks Kualitas Tutupan Lahan/Sumatera & 0,139 & 0,200 & Normal \\
\hline 10 & Indeks Kualitas Lingkungan Hidup/Sumatera & 0,141 & 0,200 & Normal \\
\hline 11 & Luas Hutan Konservasi/Jawa & 0,261 & 0,200 & Normal \\
\hline 12 & Luas Hutan konservasi/Jawa & 0,263 & 0,163 & Normal \\
\hline 13 & Luas Hutan Produksi Terbatas/Jawa & 0,278 & 0,200 & Normal \\
\hline 14 & Luas Hutan Produksi Tetap/Jawa & 0,249 & 0,200 & Normal \\
\hline 15 & Luas Mangrove/Jawa & 0,220 & 0,200 & Normal \\
\hline 16 & Luas Ekosistem Terumbu Karang/Jawa & 0,254 & 0,200 & Normal \\
\hline 17 & Indeks Kualitas Udara/Jawa & 0,244 & 0,200 & Normal \\
\hline 18 & Indeks Kualitas Air/Jawa & 0,175 & 0,200 & Normal \\
\hline 19 & Indeks Kualitas Tutupan Lahan/Jawa & 0,195 & 0,200 & Normal \\
\hline 20 & Indeks Kualitas Lingkungan Hidup/Jawa & 0,226 & 0,200 & Normal \\
\hline 21 & Luas Hutan Konservasi/Kalimantan & 0,174 & 0,200 & Normal \\
\hline 22 & Luas Hutan konservasi/Kalimantan & 0,177 & 0,200 & Normal \\
\hline 23 & Luas Hutan Produksi Terbatas/Kalimantan & 0,224 & 0,200 & Normal \\
\hline 24 & Luas Hutan Produksi Tetap/Kalimantan & 0,230 & 0,200 & Normal \\
\hline 25 & Luas Mangrove/Kalimantan & 0,254 & 0,200 & Normal \\
\hline 26 & Luas Ekosistem Terumbu Karang/Kalimantan & 0,305 & 0,145 & Normal \\
\hline 27 & Indeks Kualitas Udara/Kalimantan & 0,349 & 0,047 & Normal \\
\hline 28 & Indeks Kualitas Air/Kalimantan & 0,170 & 0,200 & Normal \\
\hline 29 & Indeks Kualitas Tutupan Lahan/Kalimantan & 0,215 & 0,200 & Normal \\
\hline 30 & Indeks Kualitas Lingkungan Hidup/Kalimantan & 0,189 & 0,200 & Normal \\
\hline
\end{tabular}




\begin{tabular}{lllll}
\hline 31 & Luas Hutan Konservasi/Sulawesi & 0,380 & 0,007 & Tidak Berdist. Normal \\
32 & Luas Hutan konservasi/Sulawesi & 0,260 & 0,200 & Normal \\
33 & Luas Hutan Produksi Terbatas/Sulawesi & 0,371 & 0,010 & Tidak Berdistribusi Normal \\
34 & Luas Hutan Produksi Tetap/Sulawesi & 0,299 & 0,100 & Normal \\
35 & Luas Mangrove/Sulawesi & 0,354 & 0,018 & Tidak Berdistribusi Normal \\
36 & Luas Ekosistem Terumbu Karang/Sulawesi & 0,252 & 0,200 & Normal \\
37 & Indeks Kualitas Udara/Sulawesi & 0,221 & 0,200 & Normal \\
38 & Indeks Kualitas Air/Sulawesi & 0,238 & 0,200 & Normal \\
39 & Indeks Kualitas Tutupan Lahan/Sulawesi & 0,197 & 0,200 & Normal \\
40 & Indeks Kualitas Lingkungan Hidup/Sulawesi & 0,169 & 0,200 & Normal \\
\hline
\end{tabular}

Berdasarkan Uji Kolmogorov Smirnov pada tabel 2 di atas maka untuk variabel luas hutan produksi terbatas, Pulau Sumatera dan Pulau Sulawesi tidak berdistribusi normal dan selanjutnya untuk variabel ini hanya dilakukan Independent Sample Test. Pulau Sumatera dan Pulau Sulawesi juga tidak berdistribusi normal untuk data variabel luas mangrove, sehingga untuk data Pulau Jawa dan Kalimantan dilakukan Independent Sample Test untuk dua variabel yakni luas hutan produksi terbatas dan luas mangrove. Sedangkan untuk variabel luas ekosistem terumbu karang, data Pulau Sumatera tidak berdistribusi normal, sehingga tidak diikutsertakan dalam analisis variansi. Kemudian untuk variabel luas hutan konservasi, data Pulau Sulawesi tidak berdistribusi normal, sehingga tidak diikutsertakan dalam analisis variansi. Hasil-hasil analisis variansi kondisi, kualitas, dan sumber daya lingkungan dapat dilihat pada table 3.

Tabel 3. Analisis Variansi Karakteristik dan Sumber Daya Lingkungan

\begin{tabular}{|c|c|c|c|c|c|c|}
\hline \multicolumn{7}{|c|}{ ANOVA } \\
\hline & & Sum of Squares & $\mathrm{df}$ & Mean Square & $\mathrm{F}$ & Sig. \\
\hline Luas Hutan konservasi (ribu & Between Groups & 4554161,752 & 3 & 1518053,917 & 3,594 &, 029 \\
\hline \multirow[t]{2}{*}{$\mathrm{Ha})$} & Within Groups & 9713699,694 & 23 & 422334,769 & & \\
\hline & Total & 14267861,445 & 26 & & & \\
\hline \multirow{3}{*}{$\begin{array}{l}\text { Luas Hutan Produksi Tetap } \\
\text { (ribu Ha) }\end{array}$} & Between Groups & 13377520,542 & 3 & 4459173,514 & 5,478 &, 005 \\
\hline & Within Groups & 18722471,604 & 23 & 814020,505 & & \\
\hline & Total & 32099992,147 & 26 & & & \\
\hline \multirow[t]{3}{*}{ Indeks Kualitas Udara } & Between Groups & 602,501 & 3 & 200,834 & 14,101 &, 000 \\
\hline & Within Groups & 327,574 & 23 & 14,242 & & \\
\hline & Total & 930,076 & 26 & & & \\
\hline \multirow[t]{3}{*}{ Indeks Kualitas Air } & Between Groups & 599,654 & 3 & 199,885 & 5,511 &, 005 \\
\hline & Within Groups & 834,171 & 23 & 36,268 & & \\
\hline & Total & 1433,825 & 26 & & & \\
\hline Indeks Kualitas Tutupan & Between Groups & 4236,209 & 3 & 1412,070 & 8,511 &, 001 \\
\hline \multirow[t]{2}{*}{ Lahan } & Within Groups & 3815,888 & 23 & 165,908 & & \\
\hline & Total & 8052,098 & 26 & & & \\
\hline Indeks Kualitas Lingkungan & Between Groups & 1477,281 & 3 & 492,427 & 12,697 &, 000 \\
\hline \multirow{2}{*}{ Hidup } & Within Groups & 891,990 & 23 & 38,782 & & \\
\hline & Total & 2369,271 & 26 & & & \\
\hline
\end{tabular}

Tabel 3 memuat analisis variansi untuk variabel luas hutan konservasi, luas hutan produksi tetap, Indeks Kualitas Udara, Indeks Kualitas Air, Indeks Kualitas Tutupan Lahan, dan Indeks Kualitas Lingkungan Hidup. Karena untuk 6 variabel ini, data keempat pulau berdistribusi normal. Hasil analisis variansi signifikan didapatkan untuk keenam variabel tersebut, dalam artian bahwa dalam perbandingan enam variabel karakteristik dan sumber daya lingkungan provinsi - provinsi pada empat pulau besar tersebut signifikan perbedaannya, karena diperoleh statistik F yang cukup tinggi sehingga nilai sig. $<0,05$. 
Indeks kualitas udara menurut Keputusan Menteri Negara Lingkungan Hidup Nomor: KEP 45/MENLH/1997 adalah alat ukur sederhana berupa angka yang memberikan informasi tentang kualitas udara suatu daerah dan data ini di peroleh dari pengolahan data hasil pemantauan kualitas udara tahunan. Kementerian Lingkungan hidup melakukan perhitungan IKU Nasional dan IKU Provinsi. IKU provinsi di gunakan untuk menghitung IKU Nasional yang di dasarkan pada data hasil pemnatauan kualitas udara ambien dengan metode manual passive( Rita dkk, 2018). Indeks kualitas air merupakan sebuah nilai yang yang di dapatkan dari pendekatan menggambarkan kualitas air dengan menggambungkan beberapa hasil pengukuran parameter kualitas air (Radiarta \& Erlania, 2015). Perbedaan- perbedaan indeks-indeks di atas dapat dikarenakan karena adanya perbedaan kondisi lingkungan, jenis kegiatan masyarakat, jumlah penduduk dan faktor lainnya.

Tabel 4. Analisis Variansi Luas Ekosistem Terumbu Karang

\begin{tabular}{|c|c|c|c|c|c|}
\hline \multicolumn{6}{|c|}{ ANOVA } \\
\hline Luas Ekosistem $\mathrm{T} \epsilon$ & Irang (ribu Ha) & & & & \\
\hline & Sum of Squares & $\mathrm{df}$ & Mean Square & $\mathrm{F}$ & Sig. \\
\hline Between Groups & 58245,507 & 2 & 29122,753 & 4,744 &, 027 \\
\hline Within Groups & 85936,083 & 14 & 6138,292 & & \\
\hline Total & 144181,590 & 16 & & & \\
\hline
\end{tabular}

Tabel 4 menyajikan hasil analisis variansi untuk perbandingan Pulau Jawa, Pulau Kalimantan, dan Pulau Sulawesi dalam hal luas ekosistem terumbu karang. Kolom sig bernilai 0,027, nilai ini $<0,05$, artinya terdapat perbedaan yang signifikan untuk luas ekosistem terumbu karang pada Pulau Jawa, Pulau Kalimantan, dan Pulau Sulawesi. Hal ini dikarenakan jumlah luasan terumbu karang pada pulau jawa sendiri hanya mencapai 23,38861, sedangkan Pulau Kalimantan mencapai 117,87717 dan Pulau Sulawesi mencapai 805,27296 . Permasalahan pengelolaan sumberdaya terumbu karang bersifat sangat dinamis bentuk pemanfaatan dan pengelolaan setiap daerah juga berbeda-beda. Tekanan dan ancaman terhadap sumberdaya terumbu karang adalah kegiatan pemanfaatan dan eksploitasi terumbu karang yang tidak ramah lingkungan (Arkham dkk, 2021). Oleh karena itu, perlu adanya penelaahan lebih lanjut untuk melihat dan mempelajari berbagai macam pemanfaatan terumbu karang yang ramah lingkungan pada berbagai macam daerah dalam upaya penyelarasan dan konservasi yang terpadu.

Tabel 5. Analisis Variansi Luas Hutan Konservasi

\begin{tabular}{|c|c|c|c|c|c|}
\hline \multicolumn{6}{|c|}{ ANOVA } \\
\hline Luas Hutan Konse & $\mathrm{Ha})$ & & & & \\
\hline & Sum of Squares & Df & Mean Square & $\mathrm{F}$ & Sig. \\
\hline Between Groups & 572416,704 & 2 & 286208,352 & 4,334 &, 029 \\
\hline Within Groups & 1188581,987 & 18 & 66032,333 & & \\
\hline Total & 1760998,691 & 20 & & & \\
\hline
\end{tabular}

Tabel 5 memuat analisis variansi yang signifikan untuk perbandingan luas hutan konservasi antara Pulau Sumatera, Pulau Jawa dan Pulau Kalimantan. Statistik F bernilai 4,334 > nilai F Tabel, nilai sig. $<0,05$ yakni senilai 0,029. Hal ini menunjukkan bahwa terdapat perbedaan yang signifikan luas hutan konservasi pada Pulau Sumatera, Pulau Jawa, dan Pulau Kalimantan. 
Tabel 6. Independent Sample Test Perbandingan Luas Hutan Produksi Terbatas dan Luas Mangrove Provinsi - Provinsi pada Pulau Jawa dan Pulau Sumatera

\begin{tabular}{|c|c|c|c|c|c|c|c|c|c|c|}
\hline \multicolumn{11}{|c|}{ Independent Samples Test } \\
\hline & & \multirow{3}{*}{\multicolumn{4}{|c|}{$\begin{array}{l}\text { Levene's Test for } \\
\text { Equality of } \\
\text { Variances }\end{array}$}} & \multirow{3}{*}{\multicolumn{5}{|c|}{ t-test for Equality of Means }} \\
\hline & & & & & & & & & & \\
\hline & & & & & & & & & & \\
\hline & & \multirow[t]{2}{*}{$\mathrm{F}$} & \multirow[t]{2}{*}{ Sig. } & \multirow[t]{2}{*}{$\mathrm{t}$} & \multirow[t]{2}{*}{$\mathrm{df}$} & \multirow[t]{2}{*}{$\begin{array}{l}\text { Sig. (2- } \\
\text { tailed) }\end{array}$} & \multirow[t]{2}{*}{$\begin{array}{c}\text { Mean } \\
\text { Differenc } \\
\mathrm{e}\end{array}$} & \multirow[t]{2}{*}{$\begin{array}{l}\text { Std. Error } \\
\text { Differenc } \\
\text { e }\end{array}$} & \multicolumn{2}{|c|}{$\begin{array}{l}\text { 95\% Confidence } \\
\text { Interval of the } \\
\text { Difference }\end{array}$} \\
\hline & & & & & & & & & Lower & Upper \\
\hline $\begin{array}{l}\text { Luas Hutan } \\
\text { Produksi }\end{array}$ & $\begin{array}{l}\text { Equal variances } \\
\text { assumed }\end{array}$ & 12,437 &, 006 & $-2,36$ & 9 &, 042 & $-2053,776$ & 868,18571 & $-4017,74$ & $-89,80415$ \\
\hline $\begin{array}{l}\text { Terbatas (ribu } \\
\mathrm{Ha)}\end{array}$ & $\begin{array}{l}\text { Equal variances } \\
\text { not assumed }\end{array}$ & & & $-2,13$ & 4,012 & ,099 & $-2053,776$ & 961,42777 & $-4719,90$ & 612,35212 \\
\hline $\begin{array}{l}\text { Luas Mangrove } \\
\text { (ribu } \mathrm{Ha} \text { ) }\end{array}$ & $\begin{array}{l}\text { Equal variances } \\
\text { assumed }\end{array}$ & 13,862 &, 005 & $-3,93$ & 9 & ,003 & $-105,6627$ & 26,85719 & $-166,417$ & $-44,90755$ \\
\hline & $\begin{array}{l}\text { Equal variances } \\
\text { not assumed }\end{array}$ & & & $-3,65$ & 5,046 &, 014 & $-105,6627$ & 28,92815 & $-179,821$ & $-31,50368$ \\
\hline
\end{tabular}

Independent sample test pada perbandingan antara Pulau Jawa dan Pulau Kalimantan juga menunjukkan hasil yang signifikan (berbeda secara nyata) untuk variabel luas mangrove karena kolom sig untuk perbandingan variabel ini bernilai kurang dari 0,025. Sedangkan untuk variabel luas hutan produksi terbatas, tidak terdapat perbedaan yang signifikan untuk Pulau Jawa dan Pulau Kalimantan. Indonesia sendiri memiliki hutan mangrove terluas di dunia. Mangrove Indonesia meliputi lebih dari 50\% mangrove Asia dan hampir 25\% dari total mangrove dunia. Namun laju degradasi dan hilangnya hutan mangrove di Indonesia cukup tinggi, dalam dua hingga tiga decade terakhir, tercatat hampir $50 \%$ dari total luasan mangrove di Indonesia telah hilang. Kegiatan buatan manusia yang menyebabkan hilangnya mangrove di Indonesia antara lain perikanan, perkebunan, pertanian, penebangan, industri, pemukiman, tambak garam, dan pertambangan (Eddy dkk, 2015).

Hasil analisis variansi pada tabel 3, tabel 4, dan tabel 5 menunjukkan perbedaan yang signifikan, sehingga dilakukan uji lanjut (Post Hoc Test). Hasil tukey HSD post hoc test untuk variabel luas hutan konservasi, luas hutan produksi tetap, indeks kualitas udara (IKU), indeks kualitas air(IKA), indeks kualitas tutupan lahan, dan indeks kualitas lingkungan hidup provinsi - provinsi pada Pulau Sumatera, Jawa, Kalimantan, dan Sulawesi dapat dilihat pada tabel 7.

Tabel 7. Tukey HSD Post Hoc Test Perbandingan Karakteristik Lingkungan dan Sumber Daya Provinsi - Provinsi di Indonesia

\begin{tabular}{|c|c|c|c|c|c|c|c|}
\hline \multicolumn{8}{|c|}{ Multiple Comparisons } \\
\hline \multicolumn{8}{|l|}{ Tukey HSD } \\
\hline & & & Mean & & & 95\% Confide & nce Interval \\
\hline Dependent Variable & (I) Pulau & (J) Pulau & $\mathrm{J})$ & Std. Error & Sig. & Lower Bound & Upper Bound \\
\hline \multirow{4}{*}{$\begin{array}{l}\text { Luas Hutan konservasi } \\
\text { (ribu } \mathrm{Ha} \text { ) }\end{array}$} & Sumatera & Jawa & 493,7266667 & 335,5929158 & , 470 & $-434,961189$ & 1422,414523 \\
\hline & & Kalimantan & $-790,1100000$ & 355,9500397 & , 148 & $-1775,13222$ & 194,912221 \\
\hline & & Sulawesi & $-106,8733333$ & 335,5929158 & ,989 & $-1035,56118$ & 821,814523 \\
\hline & Jawa & Sumatera & $-493,7266667$ & 335,5929158 & , 470 & $-1422,41452$ & 434,961189 \\
\hline
\end{tabular}




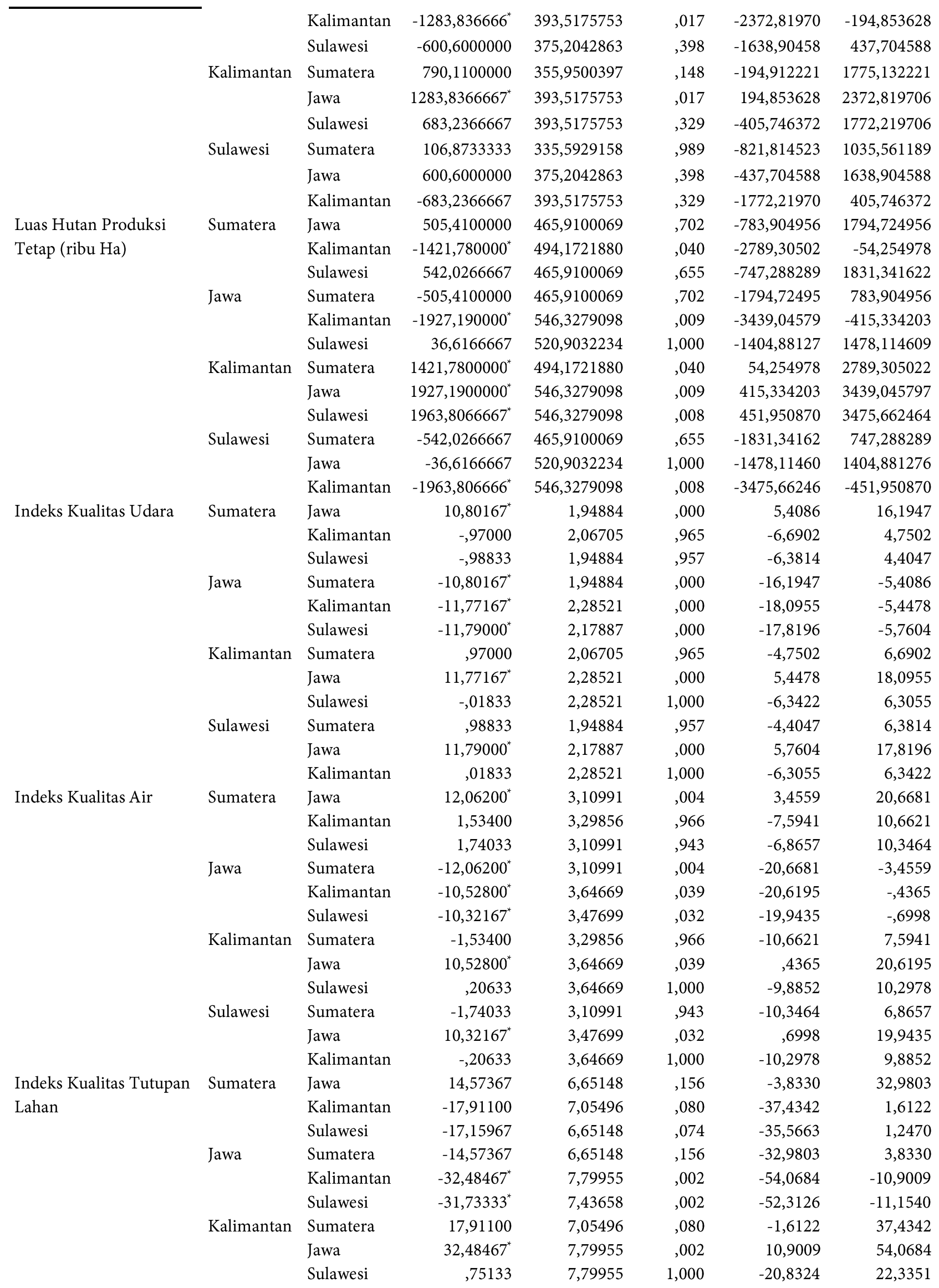




\begin{tabular}{|c|c|c|c|c|c|c|c|}
\hline & Sulawesi & Sumatera & 17,15967 & 6,65148 &, 074 & $-1,2470$ & 35,5663 \\
\hline & & Jawa & $31,73333^{*}$ & 7,43658 &, 002 & 11,1540 & 52,3126 \\
\hline & & Kalimantan &,- 75133 & 7,79955 & 1,000 & $-22,3351$ & 20,8324 \\
\hline Indeks Kualitas & Sumatera & Jawa & $12,71033^{*}$ & 3,21588 &, 003 & 3,8110 & 21,6097 \\
\hline \multirow[t]{11}{*}{ Lingkungan Hidup } & & Kalimantan & $-7,00000$ & 3,41096 & , 199 & $-16,4392$ & 2,4392 \\
\hline & & Sulawesi & $-6,62133$ & 3,21588 & , 196 & $-15,5207$ & 2,2780 \\
\hline & Jawa & Sumatera & $-12,71033^{*}$ & 3,21588 & ,003 & $-21,6097$ & $-3,8110$ \\
\hline & & Kalimantan & $-19,71033^{*}$ & 3,77096 &, 000 & $-30,1457$ & $-9,2749$ \\
\hline & & Sulawesi & $-19,33167^{*}$ & 3,59547 &, 000 & $-29,2814$ & $-9,3819$ \\
\hline & Kalimantan & Sumatera & 7,00000 & 3,41096 & , 199 & $-2,4392$ & 16,4392 \\
\hline & & Jawa & $19,71033^{*}$ & 3,77096 &, 000 & 9,2749 & 30,1457 \\
\hline & & Sulawesi & ,37867 & 3,77096 & 1,000 & $-10,0567$ & 10,8141 \\
\hline & Sulawesi & Sumatera & 6,62133 & 3,21588 & ,196 & $-2,2780$ & 15,5207 \\
\hline & & Jawa & $19,33167^{*}$ & 3,59547 &, 000 & 9,3819 & 29,2814 \\
\hline & & Kalimantan &,- 37867 & 3,77096 & 1,000 & $-10,8141$ & 10,0567 \\
\hline
\end{tabular}

Berdasarkan Tukey HSD Post Hoc Test pada tabel 7, perbedaan yang signifikan untuk variabel Luas Hutan konservasi adalah pada provinsi - provinsi di Pulau Jawa dengan Pulau Kalimantan. Sedangkan luas hutan konservasi untuk Pulau Jawa dengan Pulau Sumatera dan Pulau Sulawesi tidak memiliki perbedaan yang signifikan.

Luas Hutan Produksi tetap pada Pulau Sumatera berbeda secara nyata dengan Pulau Kalimantan. Demikian pula dengan perbandingan antara luas hutan produksi tetap pada Pulau Jawa, berbeda secara nyata dengan luas hutan produksi tetap Pulau Kalimantan. Dengan kata lain luas hutan produksi tetap Pulau Kalimantan berbeda secara nyata dengan luas hutan produksi tetap pada ketiga pulau lainnya.

Indeks Kualitas Udara (IKU) pada Pulau Sumatera berbeda secara nyata dengan Pulau Jawa, dan IKU Pulau Jawa berbeda secara nyata dengan ketiga pulau lainnya. Salah satu faktor yang menyebabkan pencemaran udara pada suatu area adalah jumlah penduduk yang nantinya akan berdampak pada kegiatan yang dilakukan oleh penduduk tersebut sehingga menyebabkan peningkatan pencemaran udara (Astusi dan Kusumawardani, 2017). Seiring dengan pernyataan tersebut, hasil pengujian yang dilakukan pada penelitian ini menunjukkan adanya perbedaan yang cukup besar dari segi jumlah penduduk dan jenis kegiatan yang terdapat pada pulau jawa dibandingkan dengan pulau lainnya. Sehingga, sangat memungkinkan sekali terjadinya perbedaan yang besar terhadap IKU di pulau jawa dengan pulau-pulau lainnya.

Indeks Kualitas Air pada Pulau Sumatera berbeda secara nyata dengan Pulau Jawa. Indeks Kualitas Air pada Pulau Jawa berbeda secara nyata dengan ketiga pulau lainnya. Perubahan pada kualitas air pada perairan umum seperti sungai sangat bergantung pada besarnya beban pencemar dari kegiatan masyarakat di sekitar perairan tersebut (Ramadhawati dkk, 2021). Perbedaan yang ditemukan pada pengujian Tukey HSD Post Hoc Test ini dinilai sejalan dengan penyataan di atas. Pulau Jawa merupakan pulau dengan penduduk padat dengan bebagai macam kegiatan yang di lakukan pada dinamika kehidupan sehari-harinya jika dibandingkan dengan pulau-pulau lainnya.

Indeks Kualitas Tutupan Lahan pada Pulau Jawa berbeda secara nyata dengan Pulau Kalimantan dan Pulau Sulawesi. Indeks Kualitas Lingkungan Hidup (IKLH) pada Pulau Jawa berbeda secara nyata dengan IKLH pada ketiga pulau lainnya. Untuk beberapa variabel karakteristik lingkungan dan sumber daya lingkungan, Pulau Jawa menunjukkan perbedaan yang signifikan dengan Pulau Sumatera, Pulau Kalimantan, dan Pulau Sulawesi. Hal ini sedikit banyak dipengaruhi oleh faktor kepadatan penduduk pada Pulau Jawa. Selanjutnya Tukey HSD Post Hoc Test untuk variabel luas ekosistem terumbu karang dapat dilihat pada tabel 8, serta Tukey HSD Post Hoc Test untuk variabel Luas Hutan Konservasi disajikan pada tabel 9. 
Tabel 8. Tukey HSD Post Hoc Test untuk Variabel Luas Ekosistem Terumbu Karang Multiple Comparisons

Dependent Variable: Luas Ekosistem Terumbu Karang (ribu Ha) Tukey HSD

\begin{tabular}{llrrrrr}
\hline & & Mean Difference & & \multicolumn{3}{c}{ 95\% Confidence Interval } \\
(I) Pulau & (J) Pulau & (I-J) & Std. Error & Sig. & Lower Bound & Upper Bound \\
\hline Jawa & Kalimantan & $-19,67733$ & 47,44162 &, 910 & $-143,8453$ & 104,4907 \\
& Sulawesi & $-130,31406^{*}$ & 45,23381 &, 031 & $-248,7036$ & $-11,9245$ \\
\multirow{2}{*}{ Kalimantan } & Jawa & 19,67733 & 47,44162 &, 910 & $-104,4907$ & 143,8453 \\
& Sulawesi & $-110,63673$ & 47,44162 &, 084 & $-234,8047$ & 13,5313 \\
Sulawesi & Jawa & $130,31406^{*}$ & 45,23381 &, 031 & 11,9245 & 248,7036 \\
& Kalimantan & 110,63673 & 47,44162 &, 084 & $-13,5313$ & 234,8047 \\
\multirow{2}{*}{ *. The mean difference is significant at the 0.05 level. } & & & & &
\end{tabular}

Tabel 8 menunjukkan bahwa menurut Tukey HSD Post Hoc Test, luas ekosistem terumbu karang pada Pulau Jawa dan Pulau Sulawesi berbeda secara nyata, sedangkan untuk luas ekosistem terumbu karang Pulau Jawa dan Pulau Kalimantan tidak berbeda secara nyata.

Tabel 9. Tukey HSD Post Hoc Test untuk Variabel Luas Hutan Konservasi

Dependent Variable: Luas Hutan Konservasi (ribu Ha)

Tukey HSD

\begin{tabular}{|c|c|c|c|c|c|c|}
\hline \multirow[b]{2}{*}{ (I) Pulau } & \multicolumn{3}{|c|}{ Mean Difference } & \multirow[b]{2}{*}{ Sig. } & \multicolumn{2}{|c|}{ 95\% Confidence Interval } \\
\hline & (J) Pulau & $(\mathrm{I}-\mathrm{J})$ & Std. Error & & Lower Bound & Upper Bound \\
\hline \multirow[t]{2}{*}{ Sumatera } & Jawa & $384,49000^{*}$ & 132,69748 & ,025 & 45,8244 & 723,1556 \\
\hline & Kalimantan & 75,36000 & 140,74694 & ,855 & $-283,8492$ & 434,5692 \\
\hline \multirow[t]{2}{*}{ Jawa } & Sumatera & $-384,49000^{*}$ & 132,69748 & 025 & $-723,1556$ & $-45,8244$ \\
\hline & Kalimantan & $-309,13000$ & 155,60159 &, 144 & $-706,2507$ & 87,9907 \\
\hline \multirow[t]{2}{*}{ Kalimantan } & Sumatera & $-75,36000$ & 140,74694 & ,855 & $-434,5692$ & 283,8492 \\
\hline & Jawa & 309,13000 & 155,60159 &, 144 & $-87,9907$ & 706,2507 \\
\hline
\end{tabular}

Tukey HSD Post Hoc Test perbandingan luas hutan konservasi pada Pulau Jawa, Sumatera, dan Kalimantan pada tabel 9 memberikan Hasil signifikan perbedaan antara luas hutan konservasi pada Pulau Jawa dan Kalimantan, sedangkan luas hutan konservasi antara Pulau Sumatera dan Pulau Kalimantan memiliki kesamaan karakteristik.

\section{Kesimpulan}

Perbedaan dan kesamaan karakteristik lingkungan dan sumber daya lingkungan berdasarkan Tukey HSD Post Hoc Test adalah pada luas hutan produksi tetap, yang menunjukkan bahwa Pulau Kalimantan berbeda dengan ketiga Pulau lainnya, kesamaan karakteristik luas hutan produksi tetap adalah untuk Pulau Sumatera, Jawa, dan Sulawesi. Pulau Jawa berbeda secara nyata dengan ketiga Pulau lainnya dalam hal Indeks Kualitas Udara dan IKLH. Perbedaan luas Hutan Konservasi yang signifikan adalah pada Provinsi Provinsi di Pulau Jawa dan Kalimantan serta Luas Ekosistem Terumbu Karang pada Pulau Jawa dan Pulau Sulawesi juga berbeda secara nyata. Sedangkan untuk variabel Luas Hutan Produksi Terbatas, tidak terdapat perbedaan yang signifikan untuk Pulau Jawa dan Pulau Kalimantan. Sedangkan hasil Independent Sample Test perbandingan luas mangrove pada Pulau Jawa dan Pulau Kalimantan juga menunjukkan hasil yang signifikan (berbeda secara nyata) dan untuk variabel Luas Hutan Produksi Terbatas, tidak terdapat perbedaan yang signifikan untuk Pulau Jawa dan Pulau KalimantanSehingga rekomendasi yang dapat 
diberikan adalah perbedaan dan kesamaan ini seyogiyanya dapat menjadi pertimbangan Pemerintah Pusat terkait Anggaran yang akan digelontorkan ke Pemerintah Provinsi. Perbedaan dan kesamaan karakteristik/sumber daya lingkungan ini juga dapat menjadi acuan bagi Pemerintah Provinsi yang akan melaksanakan Studi Komparasi serta studi adaptasi kebijakan terkait Karakteristik Lingkungan dan Sumber Daya Hutan/Tutupan Lahan.

\section{Daftar Pustaka}

[1] Arkham, M, N., Wahyudin, Y., Kelana, P, P., Haris, R, B, K., Sari, R, P.2021. Studi Penilaian Resiliensi Nelayan Dalam Pengelolaan Ekosistem Terumbu Karang Di Pulau Biawak, Kabupaten Indramayu. Samakia: Jurnal Ilmu Perikanan, 12 (1) : 1-17.

[2] Astuti, Widi dan Kusumawardani, Y. (2017). Analisis Pencemaran Udara dengan Box Model (Daya Tampung Beban Pencemar Udara) Studi Kasus di Kota Tanggerang. Jurnal Neo Telnika 3 (1): 21-28

[3] Eddy, S., A. Mulyana, M. R. Ridho, I. Iskandar. 2015. Dampak Aktivitas Antropogenik terhadap Degradasi Hutan Mangsrove di Indonesia. Jurnal Lingkungan dan Pembangunan 1(3): 240-254

[4] Harlan, J. (2018). Analisis Variansi. Depok: Gunadarma.

[5] Kementerian Lingkungan Hidup, Kepmen LH No 45 tahun 1997. (1997). Indeks Standar Pencemar Udara (ISPU)

[6] Ludwig, J.A. \& Reynolds, J.F. (1988). Statistical Ecology. USA: John Wiley \& Sons, Inc.

[7] Radiarta, I.N dan Erlania. (2015). Indeks Kualitas Air dan Sebaran Nutrient Sekitar Budidaya Laut Terintegritasi di Perairan Teluk Ekas, Nusa Ternggara Barat: Aspek Penting Budidaya Rumput Laut. Jurnal Riset Akuakultur: 10 (1) :141-152

[8] Ramadhawati, D., H.D. Wahyono, \& A.D. Santoso. (2021). Pemantauan Kualitas air Sungai Cisadane secara online dan Analisa Status Mutu Air Mneggunakan Metode Stroret. Jurnal Sains dan Teknologi Lingkungan 13(2): 76-91

[9] Rita, R. Aprishanty \& R. Fauzi. (2018). Perhitungan Indeks Kualitas Udara DKI Jakarta Menggunakan Berbagai Baku Mutu. Ecolab: 12, No. 1: 32-41

[10] Schneider, D.C. (2009). Quantitative Ecology: Measurement, Models, and Scaling. (2 ${ }^{\text {nd }}$ Edition). Canada: Elsevier.

[11] Subagyo, Pangestu, (2003). Statistik Deskriptif. Yogyakarta : BPFE-Yogyakarta

[12] Tim Penyusun. (2020). Indeks Kualitas Lingkungan Hidup 2019. Jakarta: KLHK RI.

[13] Tim Penyusun. (2020). Statistik Lingkungan Hidup Indonesia 2020. Jakarta: BPS RI. 